\title{
Pemetaan Kesesuaian Lahan Budidaya Rumput Laut Di Kecamatan Banyuputih, Situbondo Berdasarkan Indikator Kimia Air
}

\section{Suitability Mapping of Seaweed Cultivation in Banyuputih Sub-District, Situbondo Based on Water Chemistry Indicators}

\author{
Abdul Wafi ${ }^{1{ }^{*}}$, Heri Ariadi $^{2}$, Ach. Khumaidi ${ }^{1)}$, dan Abdul Muqsith ${ }^{1)}$ \\ 1) Departemen Budidaya Perikanan, Fakultas Sains dan Teknologi, Universitas Ibrahimy, \\ Situbondo. \\ 2) Program Studi Budidaya Perairan, Fakultas Perikanan, Universitas Pekalongan, Pekalongan.
}

*Penulis korespondensi : email : elfamy.wafi@gmail.com

(Diterima Juli 2021/ Disetujui September 2021)

\begin{abstract}
Seaweed cultivation is one of the aquaculture sub-activities with great potential to be developed in Banyuputih District, Situbondo. The purpose of this study was to mapping the land carryng capacity of aquaculture in the Banyuputih District, Situbondo Regency in order to be used as a seaweed cultivation area based on the existing water chemical parameter indicator values. This research was conducted in the coastal waters of Banyuputih District, Situbondo during JanuaryMarch 2019 with the concept of field research and spatial analysis from water chemistry data collection (dissolved oxygen, phosphate, and nitrate) which were then analyzed using the Inverse Distance Weighting (IDW) and overlay methods in the GIS (Geographic Information System) application to get a thematic map visualization model of land suitability. The results showed that dissolved oxygen, phosphate, and nitrate parameters fluctuated varied and dynamically during the study period, with a concentration range of 5.4-6.1 $\mathrm{mg} / \mathrm{L}(\mathrm{DO}), 0.8-1.6 \mathrm{mg} / \mathrm{L}\left(\mathrm{PO}_{4}\right)$, and 2.1$3.7 \mathrm{mg} / \mathrm{L}\left(\mathrm{NO}_{3}\right)$. This condition indicates that the Banyuputih coastal waters tend to be eutroph and suitable for use as aquaculture land activity. This statement can also be seen from the results of color visualization in the land suitability image on the research thematic map. The concentration values of the DO parameters $(5.4-6.1 \mathrm{mg} / \mathrm{L})$, phosphate $(0.8-1.6 \mathrm{mg} / \mathrm{L})$, and nitrate (2.1-3.7 $\mathrm{mg} / \mathrm{L})$ in the Banyuputih waters are also still in accordance with the water quality standards for seaweed cultivation. So from this research it can be concluded, from results various thematic map images of spatial analysis based on the existing water chemical parameter index, the location of Banyuputih Subdistrict waters is very feasible and potential to be developed as a productive seaweed cultivation area.
\end{abstract}

Keywords: Seaweed, water chemistry, carryng capacity, cultivation.

\begin{abstract}
ABSTRAK
Budidaya rumput laut adalah salah satu sub-kegiatan akuakultur yang sangat potensial untuk dikembangkan di Kecamatan Banyuputih, Situbondo. Tujuan dari penelitian ini adalah untuk memetakan kesesuaian lahan budidaya di Kecamatan Banyuputih Situbondo guna dapat digunakan sebagai area budidaya rumput laut berdasarkan nilai indikator parameter kimia air yang ada. Penelitian ini dilaksanakan di perairan pesisir Kecamatan Banyuputih, Situbondo selama bulan januari-maret 2019 dengan konsep penelitian lapang dan analisa spasial dari pengambilan data kimia air (oksigen terlarut, fosfat, dan nitrat) yang kemudian dianalisis menggunakan metode Inverse Distance Weighting (IDW) dan overlay pada aplikasi GIS (Geographic Information System) guna mendapatkan model visualisasi peta tematik kesesuaian lahan. Hasil penelitian menunjukan parameter oksigen terlarut, fosfat, serta nitrat berfluktuasi secara variatif dan dinamis selama masa penelitian berlangsung, dengan kisaran konsentrasi 5.4-
\end{abstract}

\footnotetext{
To Cite this Paper: Wafi, A., Ariadi, H., Khumaidi, A., Muqsith, A., 2021. Pemetaan Kesesuaian Lahan Budidaya Rumput Laut Di Kecamatan Banyuputih, Situbondo Berdasarkan Indikator Kimia Air. Samakia: Jurnal Ilmu Perikanan, 12 (2): 170-179.

Journal Homepage: https://journal.ibrahimy.ac.id/index.php/JSAPI
} 
$6.1 \mathrm{mg} / \mathrm{L}$ (DO), 0.8-1.6 mg/L $\left(\mathrm{PO}_{4}\right)$, dan 2.1-3.7 mg/L $\left(\mathrm{NO}_{3}\right)$. Kondisi tersebut, menandakan bahwa perairan pesisir Kecamatan Banyuputih cenderung subur dan layak untuk digunakan sebagai lahan budidaya akuakultur. Pernyataan tersebut juga bisa dilihat dari hasil visualisasi warna pada gambar kesesuaian lahan di peta tematik peneltian. Nilai konsentrasi dari parameter DO (5.4-6.1 mg/L), fosfat (0.8-1.6 mg/L), dan nitrat (2.1-3.7 mg/L) di perairan Kecamatan Banyuputih juga masih sesuai dengan ambang batas baku mutu kualitas air yang diperuntukan untuk budidaya rumput laut. Sehingga dari penelitian ini dapat disimpulkan, dari berbagai gambar peta tematik hasil analisis spasial berdasarkan indeks parameter kimia air yang ada, lokasi perairan Kecamatan Banyuputih sangat layak dan potensial untuk dikembangkan sebagai area budidaya rumput laut yang produktif.

Kata kunci: Rumput laut, Kimia air, Kesesuaian lahan, budidaya.

\section{PENDAHULUAN}

Kabupaten Situbondo merupakan satu diantara beberapa daerah basis usaha perikanan di Provinsi Jawa Timur (Muqsith et al, 2021). Wilayah pesisir pantai Kecamatan Banyuputih adalah salah satu wilayah di Kabupaten Situbondo yang memiliki potensi sumberdaya perairan untuk pengembangan usaha akuakultur. Pengembangan pemanfaatan potensi kegiatan akuakultur di perairan pesisir Kabupaten Situbondo dewasa ini diarahkan secara optimal untuk meningkatkan kesejahteraan masyarakat pesisir dengan konsep sustainable aquaculture. Sustainable aquaculture adalah konsep budidaya berkelanjutan yang terfokus pada peningkatan efisiensi produksi budidaya yang diimbangi dengan dampak lingkungan yang seminimal mungkin (Boyd et al, 2020).

Salah satu potensi akuakultur yang dikembangkan di wilayah Banyuputih adalah kegiatan budidaya rumput laut. Rumput laut merupakan slaah satu komoditas akuakultur penting yang memiliki peran untuk mengurangi dampak pencemaran lingkungan akibat polutan anorganik dan perubahan iklim (Erlania dan Radiarta, 2014). Rumput laut merupakan salah satu sumberdaya laut yang memiliki beragam manfaat untuk kegiatan industri makanan, farmasi, kecantikan dan lainnya (Asni, 2015). Rumput laut juga memiliki kandungan karbohidrat, protein,lemak, dan beberapan senyawa bioaktif lainnya (Safia et al, 2020). Selain itu, permintaan akan produksi rumput laut untuk keperluan pasar domestik dan luar negeri beberapa tahun ini terus meningkat, sehingga memberikan peluang yang sangat besar untuk pengembangan budidaya rumput laut di Indonesia (Hikmah, 2015).

Budidaya rumput laut juga tidak lepas dari pengaruh faktor kimia kualitas air pada lokasi perairan budidaya. Kualitas air adalah indikator penting yang sangat berpengaruh terhadap jalannya aktifitas budidaya akuakultur (Ariadi et al, 2019). Nilai parameter kualitas air yang bagus akan berdampak pada tingkat produktifitas budidaya yang meningkat (Ariadi et al, 2020). Beberapa parameter kimia air yang sangat berpengaruh terhadap tingkat produktifitas panen rumput laut adalah parameter oksigen terlarut, fosfat, dan nitrat. Ketiga parameter tersebut dalam kegiatan akuakultur memiliki peran yang vital terhadap dinamika ekosistem budidaya (Ariadi et al, 2021).

Melihat begitu pentingnya keberadaan indikator kimia dari parameter kualitas air terhadap ekosistem dan tingkat produktifitas budidaya (Ariadi et al, 2019). Serta, permintaan pasar akan produk rumput laut yang terus meningkat dalam beberapa waktu belakangan ini, maka tujuan dari penelitian ini adalah untuk memetakan kesesuaian lahan budidaya di Kecamatan Banyuputih Situbondo guna dapat digunakan sebagai area budidaya rumput laut berdasarkan nilai indikator parameter kimia air yang ada. Sehingga kedepannya diharapkan ada kawasan khusus di Kabupaten Situbondo yang bertindak sebagai sentra kegiatan budidaya rumput laut..

\section{MATERI DAN METODE}

Penelitian ini dilaksanakan di area perairan kawasan pesisir Kecamatan Banyuputih, Kabupaten Sirubondo pada bulan januari sampai maret 2019. Pada penelitian ini jenis data yang digunakan adalah data yang berkaitan dengan parameter kimia kualitas air pada budidaya rumput laut, yakni parameter oksigen terlarut dan nutrien perairan (fosfat dan nitrat) yang diambil dari 7 titik stasiun pengamatan. Berdasarkan data tersebut akan dibuat interpolasi yang bertujuan untuk memprediksi

To Cite this Paper: Wafi, A., Ariadi, H., Khumaidi, A., Muqsith, A., 2021. Pemetaan Kesesuaian Lahan Budidaya Rumput Laut Di Kecamatan Banyuputih, Situbondo Berdasarkan Indikator Kimia Air. Samakia: Jurnal IImu Perikanan, 12 (2): $170-179$. 
nilai grid yang tidak diwakili oleh titik sampel. Interpolasi yang digunakan yaitu Inverse Distance Weighting (IDW). Hasil dari poligon atau coverage (layer) dari tahap interpolasi ini kemudian akan digunakan untuk proses overlay. Dari tahap overlay akan dibuatkan suatu model kesesuaian lahan dalam bentuk peta. Model adalah suatu bentuk visual dari rancangan sebuah konsep untuk menjawab suatu permasalahan dalam fenomena studi kasus (Wafi et al, 2020).

Sebelum tahapan overlay disusun, dilakukan terlebih dahulu pembuatan tabel kelas kesesuaian lahan untuk budidaya rumput laut yang memuat informasi kriteria dari parameter yang ada. Selanjutnya dilakukan scoring dan pembobotan untuk menentukan kelas kesesuaian seperti pada Tabel 1. Hasil akhir dari proses overlay model adalah diperolehnya rangking atau urutan kelas kesesuaian lahan untuk budidaya rumput laut berdasarkan kisaran nilai indeks kesesuaiannya. Kelas kesesuaian lahan tersebut dibedakan menjadi 3 tingkat kelas, yaitu Kelas S1 (tidak sesuai), Kelas S2 (sesuai bersyarat), Kelas S3 (sangat sesuai). Untuk mendapatkan nilai selang indeks pada setiap kelas kesesuaian ditentukan dengan cara membagi selang antara 3 bagian yang sama dari selisih nilai indeks overlay tertinggi dengan nilai indeks overlay terendah yang diperoleh.

Tabel 1. Matrik kesesuaian lahan budidaya rumput laut di Kecamatan Banyuputih, Kabupaten Situbondo

\begin{tabular}{|c|c|c|c|c|}
\hline \multirow[b]{2}{*}{ Parameter } & \multicolumn{3}{|c|}{ Skor (S) } & \multirow[b]{2}{*}{ Bobot (B) } \\
\hline & $\begin{array}{c}\text { Tidak sesuai } \\
1\end{array}$ & $\begin{array}{c}\text { Sesuai } \\
3\end{array}$ & $\begin{array}{c}\text { Sangat Sesuai } \\
5\end{array}$ & \\
\hline 1. DO (mg/l) & $<4$ atau $>7$ & $6,1-7$ & $4-6$ & 5 \\
\hline 2. Nitrat $(\mathrm{mg} / \mathrm{l})$ & $\begin{array}{c}<0,01 \text { atau }> \\
1,0\end{array}$ & $0,8-1,0$ & $0,01-0,07$ & 5 \\
\hline 3. Phosphat $(\mathrm{mg} / \mathrm{l})$ & $\begin{array}{c}<0,01 \text { atau }> \\
0,30\end{array}$ & $0,21-0,30$ & $0,10-0,20$ & 5 \\
\hline
\end{tabular}

\section{HASIL DAN PEMBAHASAN}

\section{Indikator Parameter Kimia Air}

Nilai konsentrasi parameter kualitas air hasil analisa dari 7 titik stasiun pengamatan di pesisir pantai Kecamatan Banyuputih dapat dilihat pada Tabel 2. Nilai parameter kimia (oksigen terlarut, nitrat, fosfat) pada wilayah perairan pantai pesisir Banyuputih masih tergolong bagus dan variasinya stabil. Untuk kegiatan budidaya parameter oksigen terlarut dianjurkan untuk selalu $>4$ $\mathrm{mg} / \mathrm{L}$ (Ariadi et al, 2019). Sedangkan kadar nitrat dan fosfat yang kelewat tinggi menandakan perairan di pesisir Banyuputih bersifat eutrofik.Perairan eutrofik adalah perairan dengan kadar nutrien tinggi dan sangat mendukung untuk tumbuhnya algae atau tumbuhan air pada perairan tersebut (Suryanto dan Umi, 2009). Kadar nutrien yang tinggi dimungkinkan karena adanya limpasan limbah antropogenik dari lingkungan sekitar perairan (Zulfia dan Aisyah, 2013).

Tabel 2. Parameter kimia kualitas air di perairan Banyuputih

\begin{tabular}{cccccccc}
\hline \multirow{2}{*}{ Parameter } & \multicolumn{7}{c}{ Stasiun } \\
\cline { 2 - 8 } & St 1 & St 2 & St 3 & St 4 & St 5 & St 6 & St 7 \\
\hline DO (mg/l) & $5,4 \pm 0,2$ & $5,9 \pm 0,4$ & $6,0 \pm 0,3$ & $6,1 \pm 0,3$ & $6,0 \pm 0,4$ & $5,6 \pm 0,2$ & $6,0 \pm 0,5$ \\
Nitrat (mg/l) & $3,1 \pm 1,2$ & $3,2 \pm 1,4$ & $2,7 \pm 0,9$ & $2,1 \pm 0,6$ & $2,6 \pm 0,8$ & $3,3 \pm 1,6$ & $3,7 \pm 2,2$ \\
Fosfat (mg/l) & $0,9 \pm 0,6$ & $1,3 \pm 1,1$ & $1,6 \pm 0,5$ & $1,3 \pm 0,4$ & $1,6 \pm 0,3$ & $0,9 \pm 0,2$ & $0,8 \pm 0,5$ \\
\hline
\end{tabular}

Wilayah pesisir yang identik dengan daerah muara sangat rentan terjadinya intrusi polusi dari limbah rumah tangga yang berasal dari darat. Limbah ini memiliki kandungan unsur hara yang tinggi sehingga akan secara cepat mebingkatkan status trofik perairan (Zulfia dan Aisyah, 2013). Kondisi unsur hara yang berlebih di perairan atau dikenal dengan istilah eutrofikasi akan menyebabkan timbulnya blooming fitoplankton. Fitoplankton sebagai mikroorganisme akuatik memiliki struktur komunitas yang mudah berubah akibat perubahan kondisi fisika, kimia, dan

To Cite this Paper: Wafi, A., Ariadi, H., Khumaidi, A., Muqsith, A., 2021. Pemetaan Kesesuaian Lahan Budidaya Rumput Laut Di Kecamatan Banyuputih, Situbondo Berdasarkan Indikator Kimia Air. Samakia: Jurnal IImu Perikanan, 12 (2): $170-179$. 
biologi dari ekosistem perairan (Gurning et al, 2020). Sedangkan rumput laut, merupakan tumbuhan laut yang cenderung toleran terhadap perubahan unsur hara yang ada di lokasi perairan (Suparmi dan Sahri, 2009).

\section{Kesesuaian Lahan Budidaya Berdasarkan Tingkat Konsentrasi Oksigen Terlarut Perairan}

Parameter oksigen terlarut selama masa penelitian cenderung fluktuatif untuk setiap titik lokasi pengamatan (Gambar 1.). Hasil pengukuran oksigen terlarut berkisar antara 5,0-6,3 mg/l dengan

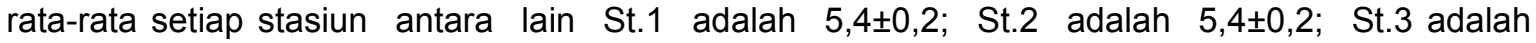

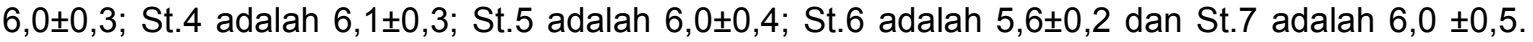
Hasil pengukuran oksigen terlarut di wilayah perairan lokasi penelitian ini dalam kondisi sangat bagus dan masih bersifat alami untuk budidaya rumput laut jenis karena nilai oksigen terlarut terendah adalah $5 \mathrm{mg} / \mathrm{l}$. Sebab apabila oksigen terlarut lebih rendah dari $4 \mathrm{mg} / \mathrm{l}$ dapat diindikasikan perairan tersebut mengalami gangguan (kekurangan oksigen) akibat kenaikan suhu, tingginya respirasi organisme air, dan pencemaran yang disebabkan oleh adanya lapisan limbah minyak di permukaan air laut serta masuknya limbah organik yang mudah terlarut. Oksigen akan berfluktuasi secara diurnal mengikuti trend kelarutan suhu di perairan (Ariadi et al, 2019).

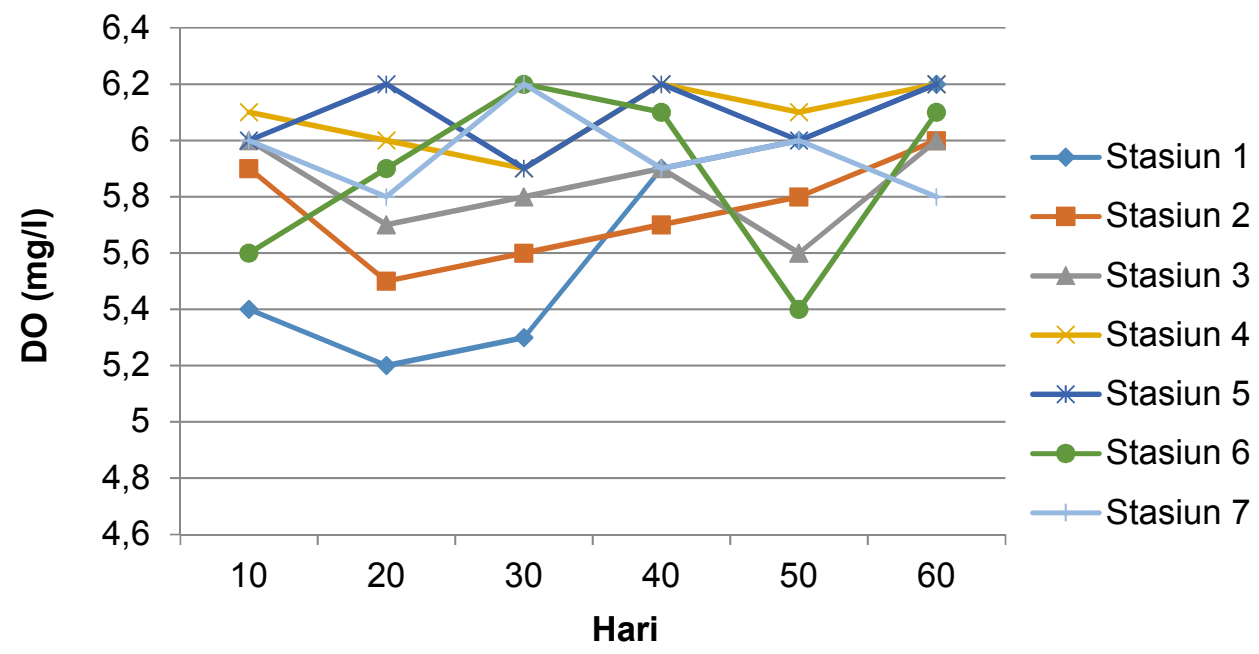

Gambar 1. Kadar Oksigen terlarut di perairan Kecamatan Banyuputih

Berdasarkan grafik diatas dapat dilihat dengan jelas bahwa fluktuasi nilai oksigen antar titik sampel (stasiun) tidak terlalu besar, dimana pada hari ke-20 dan ke-50 agak lebih rendah jika dibandingkan dengan awal, hari ke-10, 30, 40 dan 60. Hal ini diduga karena adanya pengaruh dari pergerakan massa air, proses fotosintesis dan respirasi dari organisme laut termasuk fitoplankton dan algae lainnya. Fluktuasi kadar oksigen terlarut adalah catatan penting yang memiliki pengaruh besar terhadap dinamika ekosistem budidaya air laut (Mustofa, 2019). Fluktuasi oksigen terlarut, juga akan berdampak terhadap kelimpahan jenis dan jumlah mikroorganisme akuatik seperti bakteri dan plankton yang ada di suatu perairan (Ariadi et al, 2019). Pada ekosistem perairan budidaya, fluktuasi oksigen terlarut akan menentukan segala proses kimia, fisika, dan biologi di perairan (Wafi et al, 2021).

Berdasarkan data dana analisa menggunakan teknik overlay didapatkan visualisasi peta seperti pada Gambar 2. Peta tematik oksigen terlarut (Gambar 2.) menunjukkan bahwa perairan Kecamatan Banyuputih memiliki kandungan oksigen terlarut yang berfluktuasi tidak terlalu besar. Hal ini terlihat dari seluruh perairan yang diteliti memiliki kandungan oksigen terlarut yang sesuai untuk kegiatan budidaya rumput laut. Untuk budidaya rumput laut lepas pantai dianjurkan kadar kelarutan oksigen selalu diatas $4 \mathrm{mg} / \mathrm{L}$ setiap waktunya (Nur et al, 2016). Dalam studi pemetaan akuakultur, data pemetaan kelarutan oksigen sangat penting keberadaannya sebagai indikator alamiah yang akan mempengaruhi fluktuasi parameter lain (Suniada dan Realino, 2014)

\footnotetext{
To Cite this Paper: Wafi, A., Ariadi, H., Khumaidi, A., Muqsith, A., 2021. Pemetaan Kesesuaian Lahan Budidaya Rumput Laut Di Kecamatan Banyuputih, Situbondo Berdasarkan Indikator Kimia Air. Samakia: Jurnal Ilmu Perikanan, 12 (2): 170-179. 


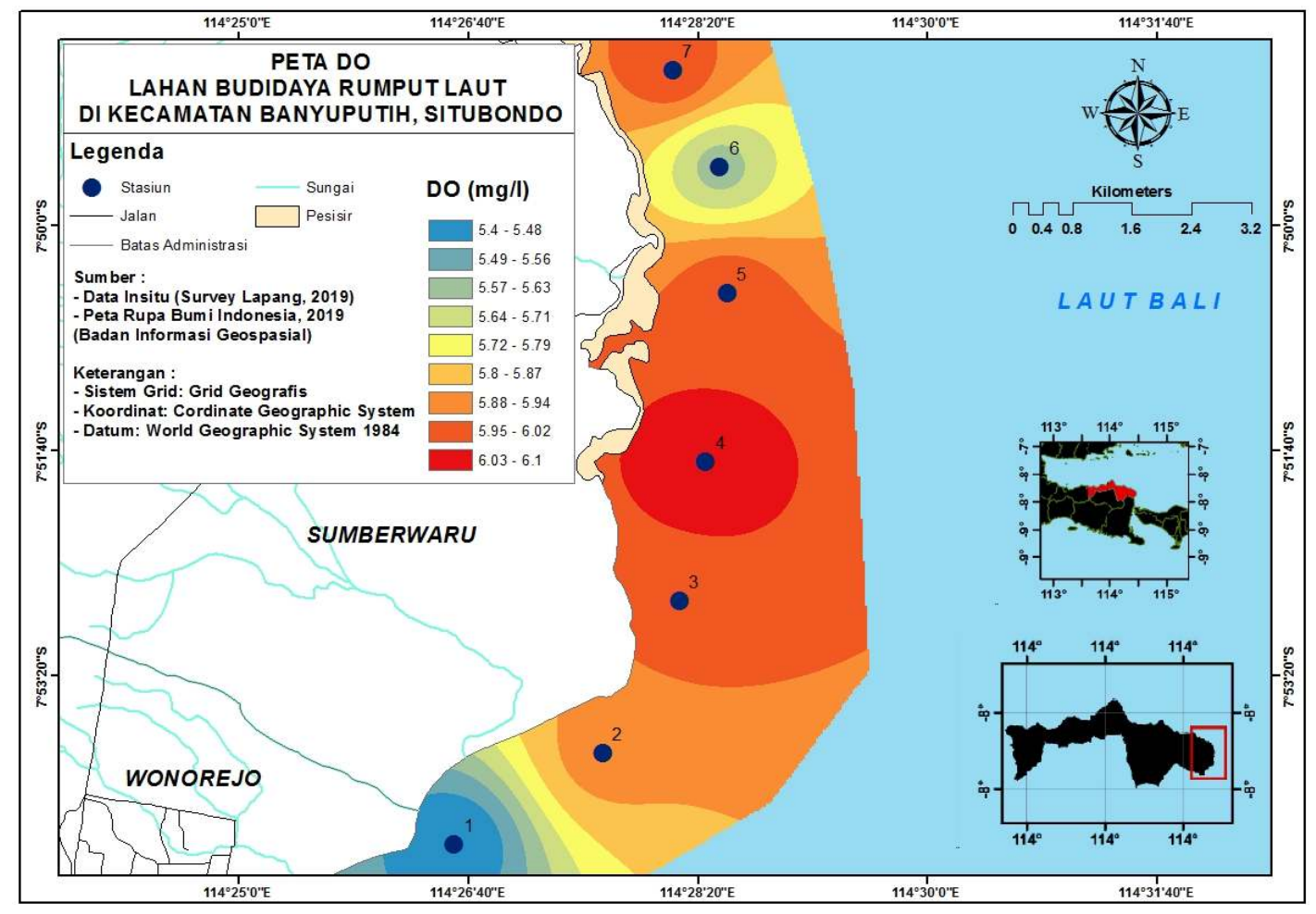

Gambar 2. Peta tematik oksigen terlarut perairan Kecamatan Banyuputih

\section{Kesesuaian Lahan Budidaya Berdasarkan Kadar Nitrat Perairan}

Nitrat di perairan laut, digambarkan sebagai senyawa mikronutrien pengontrol produktivitas primer di lapisan permukaan daerah eufotik. Keseimbangan konsentrasi nitrat di perairan sangat dipengaruhi oleh ketersediaan oksigen terlarut yang mencukupi (Sahrijanna dan Sutrisyani, 2009). Nitrat pada perairan budidaya tidak bersifat toksik. Kadar nitrat pada ekosistem budidaya rumput laut berkisar antara 0.01-0.7 mg/L (Sahrijanna dan Sutrisyani, 2009). Hasil pengukuran selama penelitian, menunjukan bahwa kadar nitrat di perairan pesisir Kecamatan Banyuputih bervariasi untuk setiap titik lokasi pengambilan sampel (Gambar 3.). Hasil pengukuran nitrat di perairan penelitian bervariasi antara $1,8-4,5 \mathrm{mg} / \mathrm{l}$ dengan rata-rata setiap stasiun antara lain St.1 yaitu $3,1 \pm 1,2$; St.2 yaitu $3,2 \pm 1,4$; St. 3 yaitu $2,7 \pm 0,9$; St.4 yaitu $2,1 \pm 0,6$; St. 5 yaitu $2,6 \pm 0,8$; St. 6 yaitu $3,3 \pm 1,6$ dan St.7 yaitu $3,7 \pm 2,2$ (Tabel 11).

Variasi konsentrasi nitrat yang dinamis pada lokasi tempat penelitian disebabkan karena wilayah sampling berada tidak jauh dengan Selat Bali yang merupakan lokasi perairan aktif untuk kegiatan penyeberangaan ataupun ruaya ikan, sehingga memingkinkan memiliki kadar unsur hara yang berlimpah dan variatif. Sirkulasi sebaran arus di Selat Bali tergolong tinggi, kondisi ini akan membuat unsur hara menjadi berlimpah di perairan tersebut (Megawati et al, 2014). Siklus sebaran nutrien dan arus di Selat Bali berlangsung secara periodik setiap tahunnya (Saputra et al, 2017). Selain itu lokasi penelitian yang berdekatan dangan titik pertemuan antara Selat Bali dengan Selat Madura dan Samudera Hindia memungkinkan terjadinya percampuran suplai nitrat yang cukup tinggi dari masing-masing perairan.

Berdasarkan analisa spasial, didapatkan gambar peta tematik sebaran nitrat di lokasi perairan tempat peneltian seperti pada Gambar 4. Dari hasil visualisasi peta tematik menunjukan bahwa kadar nitrat di perairan Kecamatan Banyuputih tergolong sesuai untuk kegiatan budidaya rumput laut. Kadar nitrat yang mencukupi di perairan akan menstimulus pertumbuhan sel-sel muda tanaman air seperti rumput laut dalam siklus pertumbuhan hidupnya (Sahrijanna dan Sutrisyani, 2009). Nitrat pada ekosistem perairan akan berfluktuasi secara dinamis mengikuti korelasi parameter kualitas air lainnya (Ariadi et al, 2021).

To Cite this Paper: Wafi, A., Ariadi, H., Khumaidi, A., Muqsith, A., 2021. Pemetaan Kesesuaian Lahan Budidaya Rumput Laut Di Kecamatan Banyuputih, Situbondo Berdasarkan Indikator Kimia Air. Samakia: Jurnal IImu Perikanan, 12 (2): $170-179$. 


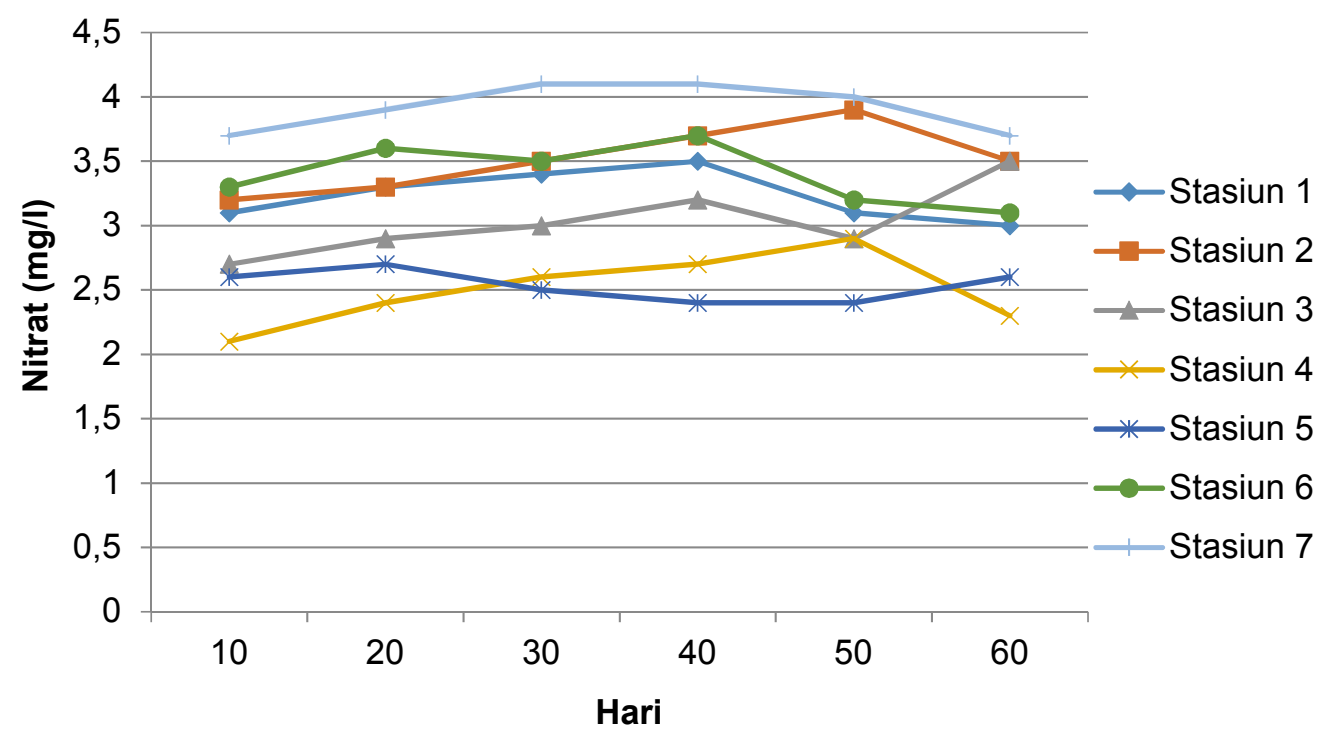

Gambar 3. Kadar Nitrat di perairan Kecamatan Banyuputih

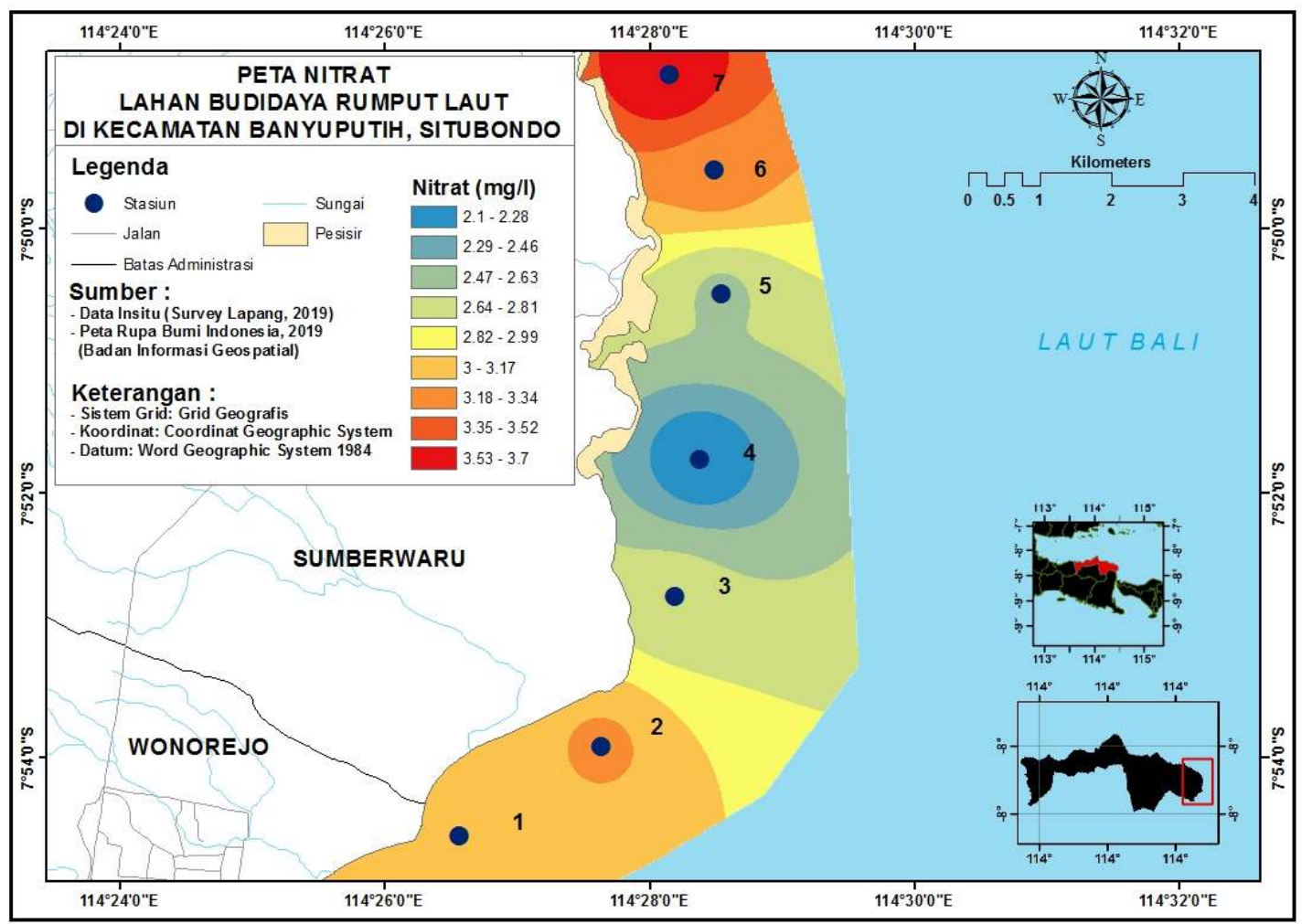

Gambar 4. Peta tematik sebaran nitrat di perairan Kecamatan Banyuputih

\section{Kesesuaian Lahan Budidaya Berdasarkan Kadar Fosfat Perairan}

Senyawa fosfat merupakan nutrisi esensialyang penting bagi pertumbuhan suatu organisme perairan (Pauwah et al, 2020). Semakin tinggi konsentrasi fosfat pada suatu perairan, menandakan bahwa perairan tersebut tergolong perairan yang subur. Konsentrasi fosfat yang cukup di suatu perairan akan sangat menentukan tingkat produktifitas pada ekosistem perairan tersebut (Halid dan Patahiruddin, 2019). Kadar fosfat pada perairan lokasi penelitian memiliki trend yang fluktuatif dan bervariasi (Gambar 5.). Kadar fosfat di lokasi penelitian berkisar antara

To Cite this Paper: Wafi, A., Ariadi, H., Khumaidi, A., Muqsith, A., 2021. Pemetaan Kesesuaian Lahan Budidaya Rumput Laut Di Kecamatan Banyuputih, Situbondo Berdasarkan Indikator Kimia Air. Samakia: Jurnal IImu Perikanan, 12 (2): $170-179$.

Journal Homepage: https://journal.ibrahimy.ac.id/index.php/JSAPI 
0,8-1,60 $\mathrm{mg} / \mathrm{l}$ dengan rata-rata setiap stasiun antara lain St 1 yaitu $0,9 \pm 0,6$; St 2 yaitu 1,3 $\pm 1,1$; St 3 yaitu $1,6 \pm 0,5$; St 4 yaitu $1,3 \pm 0,4$; St 5 yaitu $1,6 \pm 0,3$; St 6 yaitu $0,9 \pm 0,2$ dan St 7 yaitu $0,8 \pm 0,5$ (Gambar 5.).

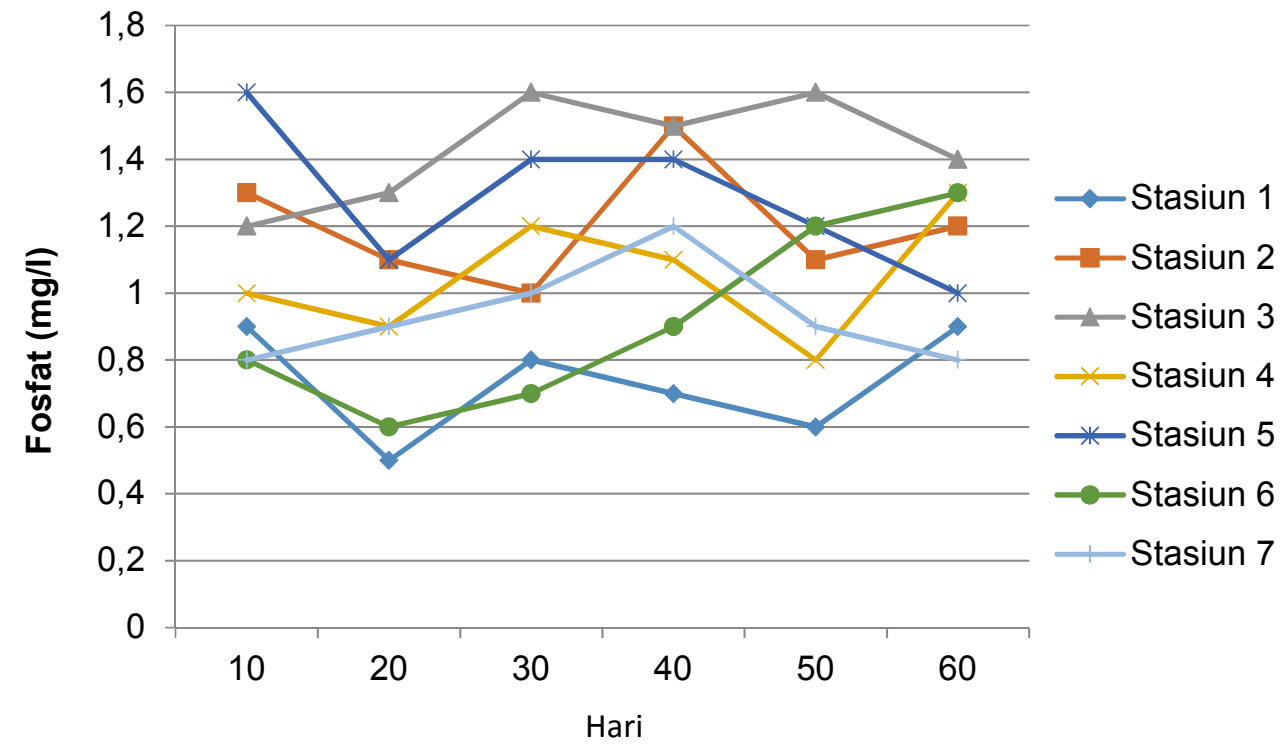

Gambar 5. Kadar fosfat di perairan Kecamatan Banyuputih

Berdasarkan grafik pada Gambar 5. ditunjukan bahwa kadar fosfat di perairan Kecamatan Banyuputih memiliki trend yang fluktuatif. Hal ini dikarenakan lokasi penelitian yang berada di lintasan pertemuan antara Selat Bali dan Selat Madura sehingga suplai nutrien fosfat yang berasal dari daratan cukup tinggi dan menyebar ke daerah titik sampling penelitian karena banyaknya sungai kecil yang bermuara ke laut di sekitar lokasi penelitian dilakukan. Sungai yang bermuara ke laut ini akan membawa limpasan fosfat yang berasal dari aktifitas rumah tangga atau kegiatan pertanian yang ada di daratan. Fosfat di perairan adalah suatu faktor pembatas nutrien yang akan mempengaruhi tingkat pertumbuhan rumput laut (Daud et al, 2014).

Berdasarkan hasil olah data overlay pada analisa spasial didapatkan visualisasi gambar peta tematik seperti pada Gambar 6. Hasil penelitian menunjukkan bahwa kadar fosfat di perairan Kecamatan Banyuputih masih berada dalam kisaran dapat menunjang bagi pertumbuhan rumput laut. Kadar fosfat yang berkisar $>0.017 \mathrm{mg} / \mathrm{L}$ sudah cukup subur untuk mendukung kegiatan budidaya rumput laut (Pauwah et al, 2020). Fosfat bersama dengan nitrat adalah dua unsur nutrien yang berperan penting dalam proses penyerapan unsur hara pada tahap pertumbuhan rumput laut dalam sistem budidaya (Budiyani et al, 2012).

Berdasarkan paparan dari berbagai data diatas secara keseluruhan dapat dikatakan bahwa secara ekologis perairan di Kecamatan Banyuputih sangat ideal untuk digunakan sebagai loaksi budidaya rumput laut. Rumput laut yang merupakan produk budidaya perairan yang potensial dan digemari oleh mayoritas masyarakat adalah jenis tumbuhan akuatik yang memiliki siklus ekologis tergantung dari keberadaan unsur hara dan kimia air (Budiyani et al, 2012). Beberapa parameter kimia penting diantaranya adalah oksigen terlarut dan unsur hara (nitrat dan fosfat). Oksigen terlarut adalah parameter utama yang mempengaruhi kelarutan nutrien dan memiliki korelasi langsung terhadap parameter kualitas air lainnya yang ada di perairan (Ariadi et al, 2020). Sedangkan fosfat dan nitrat adalah unsur hara utama yang akan mempengaruhi tingkat produktifitas perairan serta laju pertumbuhan rumput laut. Kelimpahan unsur fosfat dan nitrat di perairan umum ditentukan oleh kondisi parameter fisika kimia perairan tersebut (Megawati et al, 2014). Kondisi parameter kualitas air yang sesuai akan sangat menentukan status kelayakan ekologis dari suatu kegiatan budidaya akuakultur (Wafi et al, 2021).

\footnotetext{
To Cite this Paper: Wafi, A., Ariadi, H., Khumaidi, A., Muqsith, A., 2021. Pemetaan Kesesuaian Lahan Budidaya Rumput Laut Di Kecamatan Banyuputih, Situbondo Berdasarkan Indikator Kimia Air. Samakia: Jurnal IImu Perikanan, 12 (2): $170-179$. 


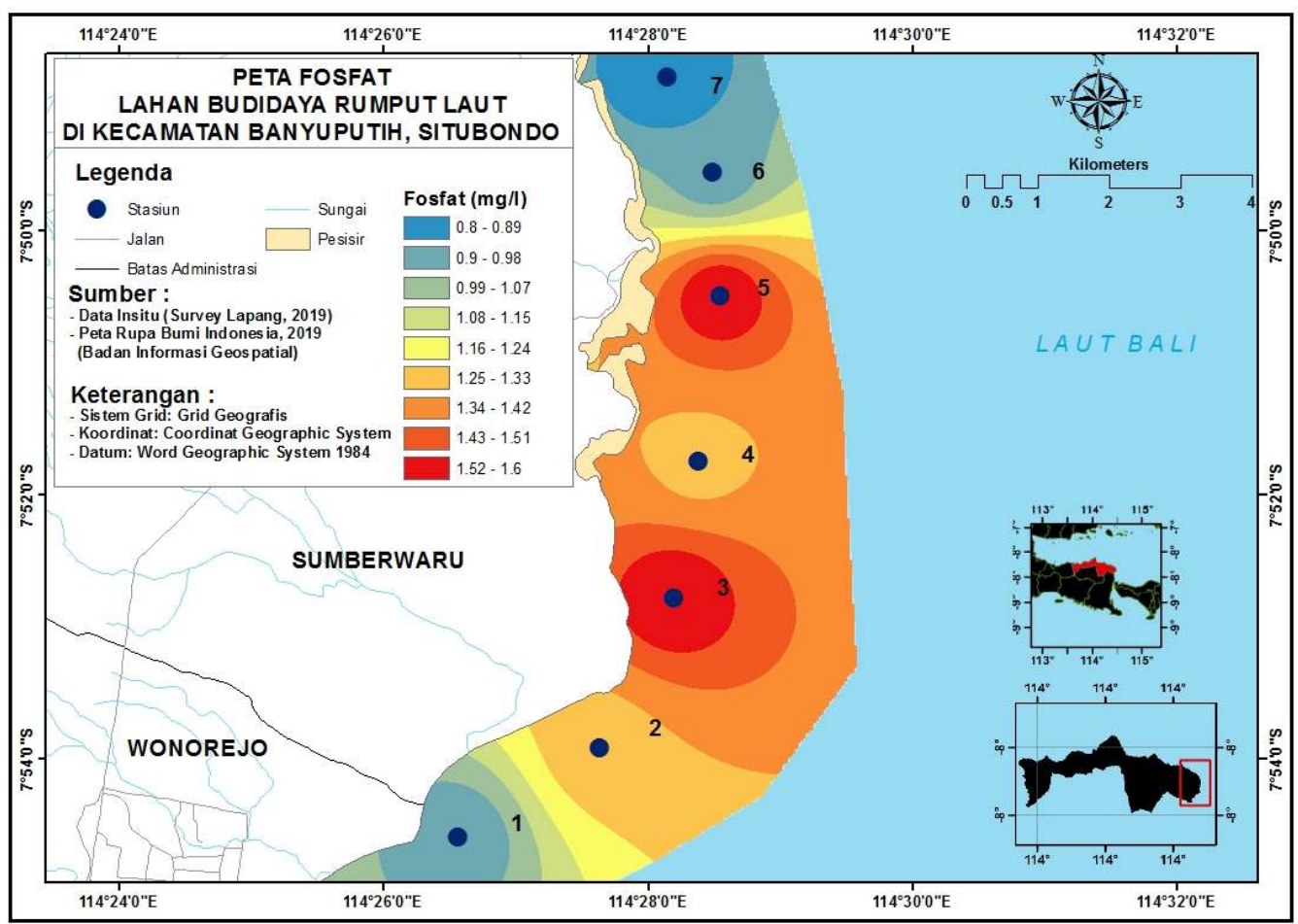

Gambar 6. Peta tematik sebaran fosfat di perairan Kecamatan Banyuputih

\section{KESIMPULAN}

Berdasarkan dari berbagai gambar peta tematik hasil analisis spasial, lokasi perairan Kecamatan banyuputih sangat layak dan potensial untuk dikembangkan sebagai area budidaya rumput laut yang produktif

\section{DAFTAR PUSTAKA}

Ariadi, H., Mahmudi M., Fadjar M. 2019. Correlation between Density of Vibrio Bacteria with Oscillatoria sp. Abundance on Intensive Litopenaeus vannamei Shrimp Ponds. Research Journal of Life Science 6(2): 114-129.

Ariadi, Fadjar M., Mahmudi M. 2019. Financial Feasibility Analysis Of Shrimp Vannamei (Litopenaeus vannamei) Culture In Intensive Aquaculture System With Low Salinity. ECSOFiM: Economic and Social of Fisheries and Marine Journal 07(01): 81-94.

Ariadi, H., Fadjar M., Mahmudi M., Supriatna. 2019. The relationships between water quality parameters and the growth rate of white shrimp (Litopenaeus vannamei) in intensive ponds. AACL Bioflux 12(6): 2103-2116.

Ariadi, H., Wafi A., dan Supriatna. 2020. Hubungan Kualitas Air Dengan Nilai FCR Pada Budidaya Intensif Udang Vanname (Litopenaeus vannamei). Samakia: Jurnal IImu Perikanan 11(1): 44-50.

Ariadi, A., Wafi A., Mahmudi M., Fadjar M. 2020. Tingkat Transfer Oksigen Kincir Air Selama Periode Blind Feeding Budidaya Intensif Udang Putih (Litopenaeus vannamei). Journal of Fisheries and Marine Research 4(1): 7-15.

Ariadi, A., Wafi A., Musa M., dan Supriatna. 2021. Keterkaitan Hubungan Parameter Kualitas Air Pada Budidaya Intensif Udang Putih (Litopenaeus vannamei). Samakia: Jurnal IImu Perikanan 12(1): 18-27.

To Cite this Paper: Wafi, A., Ariadi, H., Khumaidi, A., Muqsith, A., 2021. Pemetaan Kesesuaian Lahan Budidaya Rumput Laut Di Kecamatan Banyuputih, Situbondo Berdasarkan Indikator Kimia Air. Samakia: Jurnal IImu Perikanan, 12 (2): $170-179$.

Journal Homepage: https://journal.ibrahimy.ac.id/index.php/JSAPI 
Asni, A. 2015. Analisis Produksi Rumput Laut (Kappaphycus alvarezii) Berdasarkan Musim dan Jarak Lokasi Budidaya di Perairan Kabupaten Bantaeng. Jurnal Akuatika 6(2): 140-153.

Boyd, C.E., D'Abramo L.R.D., Glencross B.D., Huyben D.C., Juarez L.M., Lockwood G.S., McNevin A.A., Tacon A.G.J., Teletchea F., Tomasso Jr J.R., Tucker C.S., Valenti W.C. 2020. Achieving sustainable aquaculture: Historical and current perspectives and future needs and challenges. Journal of the World Aquaculture Society 51(3): 578-633.

Budiyani, F.B., Suwartimah K., sunaryo. 2012. Pengaruh Penambahan Nitrogen dengan Konsentrasi yang Berbeda terhadap Laju Pertumbuhan Rumput Laut Caulerpa racemosa var. uvifera. Journal Of Marine Research 1(1): 10-18.

Daud, R., Mulyaningrum S.R.H., dan Tjaronge M. 2014. Analisis Kualitas Air Yang Berpengaruh Terhadap Pertumbuhan Rumput Laut Gracilaria verrucosa Hasil Kultur Jaringan Di Tambak. Prosiding Forum Inovasi Teknologi Akuakultur. Jakarta: Forum Inovasi Teknologi Akuakultur: $479-483$

Erlania., dan Radiarta I.N. 2014. Management of Sustainable Seaweed (Kappaphycus alvarezii) Aquaculture In The Context of Climate Change Mitigation. Indonesian Aquaculture Journal 9(1): 65-72.

Gurning, L.F.P., Nuraini R.AT., Suryono. 2020. Kelimpahan Fitoplankton Penyebab Harmful Algal Bloom di Perairan Desa Bedono, Demak. Journal of Marine Research 9(3): 251-260.

Halid, I., dan Patahiruddin. 2019. Teknik Penggunaan Pupuk Fosfat Terhadap Rumput Laut (Gracilaria verrucosa) Di Tambak Budidaya Lakawali Kabupaten Luwu Timur Sulawesi Selatan. Jurnal Resona 3(2): 64-71.

Hikmah. 2015. Strategi Pengembangan Industri Pengolahan Komoditas Rumput Laut E. cotonii Untuk Peningkatan Nilai Tambah Di Sentra Kawasan Industrialisasi. Jurnal Kebijakan Sosial Ekonomi Kelautan Perikanan 5(1): 27-36.

Megawati, C., Yusuf M., Maslukah L. 2014. Sebaran Kualitas Perairan Ditinjau Dari Zat Hara, Oksigen Terlarut dan pH Di Perairan Selat Bali Bagian Selatan. JURNAL OSEANOGRAFI 3(2): 142-150.

Muqsith, A., Ariadi H., and Wafi A. 2021. Financial Feasibility Analysis And Business Sensitivity Level On Intensive Aquaculture Of Vaname Shrimp (Litopenaeus vannamei). ECSOFiM: Economic and Social of Fisheries and Marine Journal 08(02): 268-279.

Mustofa. 2019. Sebaran Kandungan Oksigen Terlarut Perairan Pantai Sebagai Daya Dukung Usaha Tambak Di Kabupaten Jepara. Jurnal Disprotek 10(2): 95-100.

Nur, A.I., Syam H., Patang. 2016. Pengaruh Kualitas Air Terhadap Produksi Rumput Laut (Kappaphycus alvarezii). Jurnal Pendidikan Teknologi Pertanian 2: 27-40.

Pauwah, A., Irfan M., Muchdar F. 2020. Analisis Kandungan Nitrat Dan Fosfat Untuk Mendukung Pertumbuhan Rumput Laut Kappahycus alvarezii Yang Dibudidayakan Dengan Metode Longline Di Perairan Kastela Kecamatan Pulau Ternate Kota Ternate . Hemyscyllium 1(1): 10-22.

Safia, W., Budiyanti., Musrif. 2020. Kandungan Nutrisi Dan Senyawa Bioaktif Rumput Laut (Euchema cottonii) Yang Dibudidayakan Dengan Teknik Rakit Gantung Pada Kedalaman Berbeda. Jurnal Pengolahan Hasil Perikanan Indonesia 23(2): 261-271.

\footnotetext{
To Cite this Paper: Wafi, A., Ariadi, H., Khumaidi, A., Muqsith, A., 2021. Pemetaan Kesesuaian Lahan Budidaya Rumput Laut Di Kecamatan Banyuputih, Situbondo Berdasarkan Indikator Kimia Air. Samakia: Jurnal IImu Perikanan, 12 (2): 170-179.

Journal Homepage: https://journal.ibrahimy.ac.id/index.php/JSAPI
} 
Sahrijanna, A., dan Sutrisyani. 2009. Pengamatan Kandungan Nitrat Di Sekitar Perairan Lahan Budidaya Rumput Laut (kappaphycus alvarezii) Di Tonyaman, Polewali, Sulawesi Barat. Buletin Teknik Litkayasa Akuakultur 8(2): 127-130.

Saputra, C., Arthana I.W., Hedrawan I.G. 2017. Studi Ancaman Sumber Daya Ikan Lemuru (Sardinella lemuru) Di Selat Bali Hubungannya Dengan ENSO dan IOD. ECOTROPHIC 11(2): 140-147.

Suniada, K.I., dan Realino B.S. 2014. Studi Penentuan Lokasi Untuk Pengembangan Budidaya Rumput Laut Di Wilayah Perairan Teluk Saleh, Sumbawa, NTB. Jurnal Kelautan Nasional 9(2): 81-91.

Suparmi., dan Sahri, A. 2009. Mengenal Potensi Rumput Laut : Kajian Pemanfaatan Sumberdaya Rumput Laut Dari Aspek Industri Dan Kesehatan. Sultan Agung XLIV(118): 95-116.

Suryanto, A.M., dan Umi H. 2009. Pendugaan Status Trofik Dengan Pendekatan Kelimpahan Fitoplankton Dan Zooplankton Di Waduk Sengguruh, Karangkates, Lahor, Wlingi Raya Dan Wonorejo Jawa Timur. Jurnal Ilmiah Perikanan dan Kelautan 1(1): 7-13.

Wafi, A., Ariadi H., Fadjar M., Mahmudi M., dan Supriatna. 2020. Model Simulasi Panen Parsial Pada Pengelolaan Budidaya Intensif Udang Vannamei (Litopenaeus vannamei). Samakia: Jurnal IImu Perikanan 11(2): 118-126.

Wafi, W., Ariadi H., Muqsith A., Madusari B.D. 2021. Business Feasibility of Intensive Vaname Shrimp (Litopenaeus vannamei) With Non-Partial System. ECSOFiM: Journal of Economic and Social of Fisheries and Marine 08(02): 226-238.

Wafi, A., Ariadi H., Muqsith A., Mahmudi M., and Fadjar M. 2021. Oxygen Consumption of Litopenaeus vannamei in Intensive Ponds Based on the Dynamic Modeling System. Journal of Aquaculture and Fish Health 10(1): 17-24.

Zulfia, N., dan Aisyah. 2013. Status Trofik Perairan Rawa Pening Ditinjau Dari Kandungan Unsur Hara $\left(\mathrm{NO}_{3}\right.$ dan $\left.\mathrm{PO}_{4}\right)$ Serta Klorofil-a. BAWAL 5(3): 189-199.

To Cite this Paper: Wafi, A., Ariadi, H., Khumaidi, A., Muqsith, A., 2021. Pemetaan Kesesuaian Lahan Budidaya Rumput Laut Di Kecamatan Banyuputih, Situbondo Berdasarkan Indikator Kimia Air. Samakia: Jurnal IImu Perikanan, 12 (2): $170-179$. 